\title{
MODEL OF IMPROVING ENTREPRENEUR INTENTIONS IN THE CONTEXT OF PARENTAL ROLE
}

\author{
Evita Dewi ${ }^{1^{*}}$, Widodo $^{2 *}$
}

* Affiliation:
1,2 Magister Management
Program, Sultan Agung
Islamic University Semarang
evitadewimung@ gmail.com

\begin{abstract}
:
The purpose of this study was to describe and analyze the effect of Quality of Education and Risk Taking on Entrepreneur Intentions in the context of Parental Role. The respondents of this study amounted to 300 students of class XII in 3 Vocational High School of SMKN 1 Kudus, SMK Al Islam and SMK NU Banat. Hypothesis testing was conducted using Structural Equation Modeling (SEM) with SmartPLS ver. 3 software. The results showed that with Parental Role moderation the total effect of Education Quality and Risk Taking on Entrepreneur Intentions is smaller than the total effect before moderation, meaning that Parental Role variable does not strengthen the effect of Education Quality - Entrepreneur Intentions and Risk Taking - Entrepreneur Intentions.

Keywords: Entrepreneur Intentions, Quality of Education, Risk Taking, Parental Role
\end{abstract}

\section{INTRODUCTION}

The creation of job field and work absorption which is effective, innovative and diversity may lead to economic growth. In line with that, Olanepikun, Brimah et al (2015) also stated that competition as Chidiebere Iloanya et al. (2014) stated that entrepreneur has been referred as a machine, skill and competence owned by citizen that has effect more on welfare level and economic growth of the country. While Subroto (2013) emphasized that country's failure in developing entrepreneur on their citizen may cause poverty and economic failure of that company. Conditions in which citizens have competence, skills and entrepreneurial abilities can only be realized if the country implements an educational system that allows its citizens to use both "head" and "hand". This means that in addition to providing knowledge, the state also makes its citizens competent in technology, skills and abilities of entrepreneurs (Olanipekun, Brimah et al., 2015). Fatos Bektos (2011) stated that in order to grow a vast and rapidly expanding entrepreneur, it is necessary to conduct a research to define where the intentions appear for someone to engage in an entrepreneurial activity. One of the 
distinctive characteristics of an entrepreneur is the ability to recognize a new idea and examine the feasibility of this idea along with the risk factors and possible failures related to the economic, social and political environment in which the idea will be applied. Mitka (2017) stated that an entrepreneur is required to be in a condition which is full of uncertainty or have high risktaking. This is a continuous process of thinking and planning over a long period of time. Chlosta, Patzelt et al. (2012) stated that in inculcating and fertilizing entrepreneur intentions, the parental role holds dominant factor because the interaction between parental roles and offspring is very effective in motivating and encouraging the grandchildren to continue and run the family business. By understanding entrepreneur as one of the sectors for the absorption of manpower, productivity improvement and economy of the country, therefore, the development of entrepreneur to lead to a more productive, innovative and independent society becomes one thing that can not be negotiable.

\section{REVIEW RELATED LITERATURES Entrepreneur Intentions}

Bereket Mamo Bulli and Yesuf (2015) found that economic conditions in developing countries that tend to be unstable often cause strong economic shocks. This has led to job seekers not being able to rely on their future on formal employment that resides in companies and encourages the emergence of business people or entrepreneurs. With the role, then it is common if then entrepreneur is said as a driver and backbone of the nation's economy. (Subroto 2013) said that the country should be creative in exploring and developing the structures and assets of its creative economy. The success of developed and economically emerging countries is achieved because they have successfully provided and developed the right educational model for their citizens. (Ohiwerei and Nwosu 2013) explicitly stated "No nation can develop without vocational and technical education". In order to instill and nourish entrepreneurial intentions, the ability to manage risk taking holds the dominant factor as expressed by (Chlosta, Patzelt et al. 2012). Fatos Bektos (2011) found that entrepreneurs are those with the ability to create a new idea and measure the feasibility of the idea by considering the risk factors and possible failures associated with the economic, social and political environment in which the idea will be applied. (Chlosta, Patzelt et al. 2012) further stated that the foundation of family business success will be seen as a "hero" in the family business empire. The story of the first generation that has succeeded in building a family business will be a hereditary story in the second, third and subsequent generations. This means that there is a strong parental role effect on their offspring in order to make business and entrepreneur their lifestyle choice and to see entrepreneurs as a form of career that can ensure their lives.

\section{Risk Taking}

Entrepreneurial activity is always related to situations where an entrepreneur must always analyze the environment and things that are interrelated and influencing one to each. As revealed by Mitka (2017) that an entrepreneur is required to be able to be in a situation which is full of uncertainty or having high risk-taking. Risk taking will have a greater positive impact only if done with proper management. The management includes calculation or identification 
related to the availability of existing financial resources and the market to be entered. The tendency for risk-taking has a positive impact on the level of individual innovation when products and services are implemented to the market (JoannaEjdys, 2016). Thus, risk taking means accepting a moderate risk that can benefit an entrepreneur's business venture. Therefore the first hypothesis is:

H1 : The higher risk taking, the higher entrepreneur intentions.

\section{QUALITY OF EDUCATION}

The quality of education is an interesting subject because with this education, it is expected that potential high-skilled, as well as highly skilled workforce can be self-sufficient, since knowledgeable human resources are the starting point for effective management and utilization of natural resources (Olanipekun, Brimah et al. 2015). Other studies outlined the importance of policy-makers to understand that the quality of education is a vehicle for economic and social growth (Harry Matlay, Buli et al. 2015). In the end, (Nafukho and Nkirina 2010) identified 6 (six) major problems faced by policy holders or can be interpreted by the government in the implementation of qualified education related to the creation of qualified and self-employed workers: 1) Limited time. 2) Graduates who do not have the same standard of competence. 3) Budget constraints. 4) Instructors are less competent. 5) Lack of successful entrepreneurs who can be role models. 6) Teaching is too theoretical.

Olanipekun, Brimah et al. (2015) argued that the success of developed and economically emerging countries today is achieved because they have provided and developed an appropriate model of education for their citizens, an education model that provides the competence, skills and abilities of entrepreneurs. Therefore the second hypothesis is:

$\boldsymbol{H} 2$ : The better quality of education, the higher entrepreneur intentions.

\section{PARENTAL ROLE}

The decision of an individual's career as an entrepreneur has been the focus of research by many researchers. This is primarily associated with parental roles as parental roles for their children and that parents affect the important decisions their child makes in his or her life. (Chlosta, Patzelt et al. 2012) defined the entrepreneur family as a family with entrepreneurial culture as well as having a family-run business. Growing up and growing in an entrepreneur family environment allows a child to be able to make parents as their role model and learns to understand entrepreneurs as a field of work. Understanding and involving the child in the family business activities in the end can motivate the child to later in the future continue the family business or even build and pioneer their own business. The research conducted by (Chlosta, Patzelt et al. 2012) ultimately concluded that parental roles are the main factor of an individual to become an entrepreneur despite the fact that other factors also affect. It also supports the results of research conducted by (Moi, Adeline et al. 2011) that entrepreneur role model (ERM) in the family moderates the entrepreneurial intention model. This is because the exemplary and established economy which can also be a encouragement for a child to become the successor of the family business. Therefore the fourth hypothesis is: 
H4a : Parental role model moderates the correlation of quality of education and risk taking

$\boldsymbol{H} \mathbf{4 b}$ : Parental role model moderates the correlation of quality of education and entrepreneur intentions

H4c : Parental role model moderates the correlation of risk taking and entrepreneur intentions

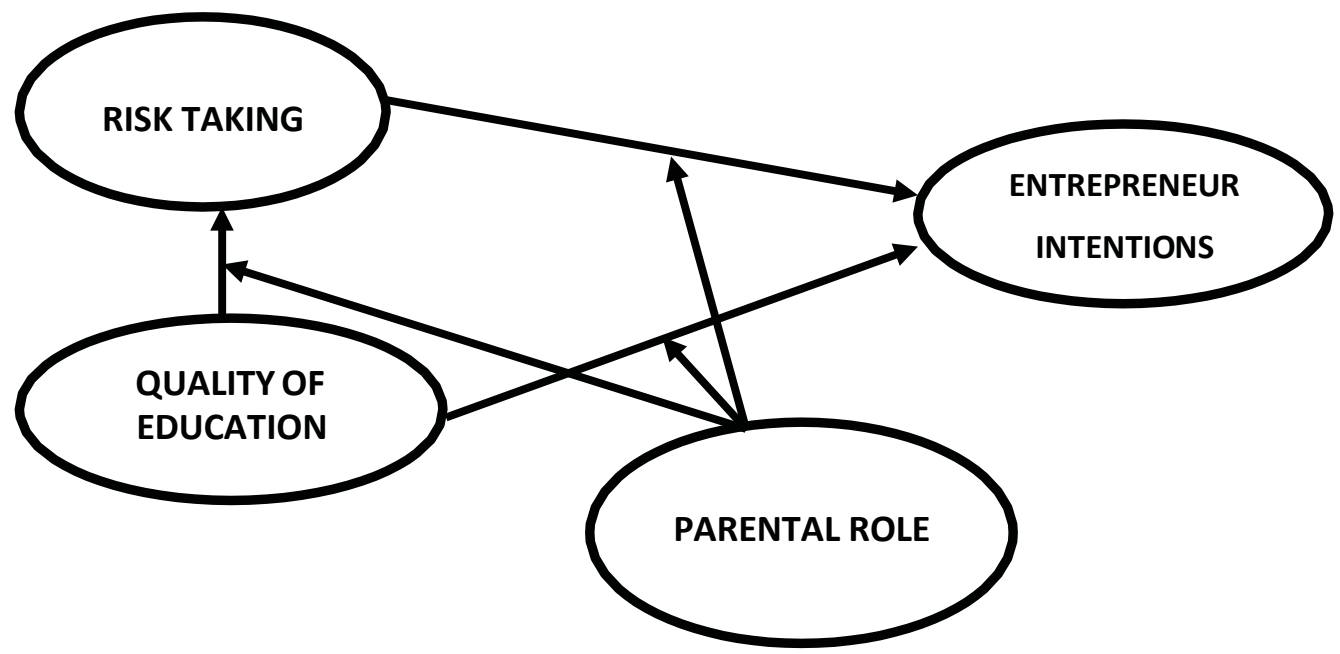

Figure 1. Empirical Model

\section{RESEARCH METHOD}

The research employed "Explanatory research", i.e. research that its nature explains relationship, difference or influence among variables through samples and hypotheses (Bungin, 2008). The data used consisted of: 1) Primary data in the form of answers / written entries of the questionnaire distributed; 2) Secondary data obtained from research journals, articles, magazines, scientific books related to this research. The respondents in this study were 300 students in 3 vocational schools in Kudus District i.e. SMKN 1 Kudus, SMK Al Islam and SMK NU Banat Kudus. The sampling method was conducted using purposive sampling. evaluating the model in PLS (SmartPLS ver.3.0) was conducted through two stages i.e. outer model or measurement model and inner model or structural model.

\section{DISCUSSION}

The evaluation of the structural model would evaluate by looking at the significance of the relationship among the variables (Path Coefficient) before and after the moderation shown by the T statistic value in the command of Calculate PLS Bootstrapping table as follows:

Table 1. The Value of Path Coefficient before Moderation

\begin{tabular}{|l|l|l|l|l|l|}
\hline & $\begin{array}{c}\text { Original } \\
\text { Sample (O) }\end{array}$ & $\begin{array}{c}\text { Sample } \\
\text { Mean (M) }\end{array}$ & $\begin{array}{l}\text { Standard } \\
\text { Deviation } \\
\text { (STDEV) }\end{array}$ & $\begin{array}{c}\text { T Statistics } \\
(\mid \mathbf{O} / \text { STDEV|) }\end{array}$ & P Values \\
\hline $\begin{array}{l}\text { Quality of Education-> Entrepreneur_- } \\
\text { Intension }\end{array}$ & 0,260 & 0,259 & 0,080 & 3,248 & 0,001 \\
\hline Quality of Education -> Risk Taking & 0,293 & 0,307 & 0,087 & 3,367 & 0,001 \\
\hline Risk Taking -> Entrepreneur_Intension & 0,518 & 0,522 & 0,060 & 8,696 & 0,000 \\
\hline
\end{tabular}

Source: Calculated Primary Data, 2017 
Table 2. The Value of Path Coefficient after Moderation

\begin{tabular}{|c|c|c|c|c|c|c|}
\hline \multicolumn{2}{|c|}{ Variable } & $\begin{array}{l}\text { Original Sample } \\
(\mathrm{O})\end{array}$ & $\begin{array}{l}\text { Sample Mean } \\
(\mathrm{M})\end{array}$ & $\begin{array}{l}\text { Standard } \\
\text { Deviation } \\
\text { (STDEV) }\end{array}$ & $\begin{array}{l}\text { T Statistics } \\
(|\mathrm{O} / \mathrm{STDEV}|)\end{array}$ & $P$ Values \\
\hline \multirow{2}{*}{\multicolumn{2}{|c|}{$\begin{array}{l}\text { Quality of Education (XI)- } \\
\text { Risk Taking (Y1) } \\
\text { Quality of Education (X1)- } \\
\text { Entrepreneur Intentions (Y2) }\end{array}$}} & 0,759 & 0,758 & 0,023 & 33,457 & 0,000 \\
\hline & & 0,612 & 0,609 & 0,042 & 14,596 & 0,000 \\
\hline \multirow{3}{*}{ 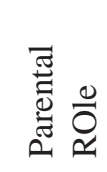 } & Moderating Effect 1 & 0,500 & 0,116 & 4,611 & 0,000 & 0,156 \\
\hline & Moderating Effect 2 & 0,400 & 0,144 & 3,405 & 0,001 & 0,909 \\
\hline & Moderating Effect 3 & 0,330 & 0,046 & 7,360 & 0,000 & 0,447 \\
\hline \multirow{2}{*}{\multicolumn{2}{|c|}{$\begin{array}{l}\text { Parental Role (Y3) - } \\
\text { Entrepreneur Intentions (Y2) } \\
\text { Risk Taking (Y1)- }\end{array}$}} & 0,629 & 0,627 & 0,034 & 18,693 & 0,000 \\
\hline & Entrepreneur Intentions (Y2) & 0,664 & 0,662 & 0,032 & 20,659 & 0,000 \\
\hline
\end{tabular}

Source: Calculated Primary Data, 2017

\section{The Effect of Risk Taking on Entrepreneur Intentions}

The first hypothesis testing obtained the value of T Statistic $20.659 \leq 1.96$ and P Value $0.000<0.05$, indicating that risk taking significantly affects the entrepreneur intentions or the hypothesis is accepted. The respondents involved in this study were all XII class students who would soon decide the field of work for their future. The world of entrepreneurs is becoming a field of work that attracts the respondents. This is because job vacancies in the formal sector are not very proportional to the number of graduates generated by senior secondary education institutions and higher education institutions. Their characteristics who can analyze the environment encourage them to become an entrepreneur. They also dare to be in a condition which is full of uncertainty or having high risk-taking. The findings of this study are in line with the opinion of Mitka (2017) which stated that Risk Taking as an important feature of an entrepreneur is taken after the identification of potential and constraints related to capital and financial strength and market conditions to be entered. This opinion is also reinforced by Mardanshahi (2015).

\section{The Effect of Quality of Education on Entrepreneur Intentions}

The second hypothesis testing obtained the value of T Statistic 14,596 $\geq 1,96$ and P Value $0.000 \leq 0,05$, showing that quality of education has positive and significant effect on entrepreneur intentions or the hypothesis is accepted. Educational system that can provide knowledge, attitude and high skills will be able to print individuals who can afford to be independent. Ohiwerei (2013) stated that education which empowers students can be a driver of economic growth of a nation so that commitment to a curriculum that can provide knowledge, skills and attitudes for learners become very important. So it can be concluded that qualified education that can empower students to be the hope of the students, their parents and the community to improve the economy of family and society. (Nafukho and Nkirina 2010). Olanipekun, Brimah et al (2015) outlined the importance for policy holders to begin to understand that the quality of education is a means for the economic and social growth of a nation. 


\section{The Effect of Quality of Education and Risk Taking}

The third hypothesis testing resulted in T Statistic score 33,457 $\geq 1,96$ and P Value 0.000 $\leq 0,05$, showed that education quality has positive and significant effect on risk taking or the hypothesis is accepted. Education is basically meant to prepare human resources before entering the labor market. Through education, a person is prepared to have a modal to be ready to know, recognize and develop methods of thinking systematically in order to solve problems that will be faced in life in the future. The result of this study is in line with the opinion (ohiwerei et al, 2103), who stated the need for an educational reform in order to create a generation capable of being independent and competing. Educational reforms are also expected to foster critical thinking, understanding, and the ability to communicate more effectively to achieve desired outcomes and to improve skills that help reduce risks in doing business.

\section{The Effect of Parental Role as a Moderating Variable}

The sixth hypothesis testing resulted a significant value of moderation effect shown through the above statistical T value of 0,$500 ; 0.00$; and 0.156 are all $\leq 1,96$ or 2 and $\mathrm{P}$ Values of 0,$400 ; 0.001$; and 0.909 all $\geq 0.05$. This shows that the parental role model is not as a moderator of the effect of the quality of education - entrepreneur intentions and risk taking - entrepreneur intentions. So from this study, it can be concluded that the high parental role does not significantly affect the quality of education and risk taking on entrepreneur intentions or the hypothesis is rejected. When compared with the result of the description of parental role model variable that obtains high criterion, this happens because it is not yet optimal use of parental role in growth and formation of entrepreneur intentions. The introduction of the entrepreneur world that has been incorporated in the national education curriculum and the understanding of the employment situation by the respondents should receive support and encouragement from the parents. External conditions such as dissatisfaction with occupation, inadequate salaries, or the desire to obtain better financial flexibility can be used by parents to increase their parental role in the growth and development of entrepreneur intentions (Nafukho, Kobia et al, 2010).

\section{Direct, Indirect, and Total Effects}

The testing on direct, indirect and total effects of each variable is presented below:

Table 3. Direct, Indirect, and Total Effects before Moderation

\begin{tabular}{lll}
\hline Correlation & Coefficient & Note \\
\hline Direct effect of quality of education -entrepreneur intentions & 0,260 & Significant \\
\hline $\begin{array}{l}\text { Indirect effect of quality of education -entrepreneur intentions } \\
\text { through risk taking }\end{array}$ & 0,152 & \\
\hline Total effect of quality of education - entrepreneur intentions & 0,412 & \\
\hline
\end{tabular}

Source: Calculated Primary Data, 2017 
From the above table, it is known that the direct effect of the variable of quality of education (X1) on entrepreneur intentions (Y2) with coefficient 0,260 and 0,152 is higher than the indirect effect through the moderation of risk taking (Y1) variable. The variable of quality of education has a total effect on entrepreneur intentions of 0.412 (41.2\%).

\section{CONCLUSION}

The purpose of this research is to develop the model of entrepreneur intentions development in the context of parental role. From the research results, it can be seen that the parental role moderation resulted in the total effect of the quality of education on improving entrepreneur intentions through risk taking of $18.6 \%$. When compared with before moderation, the total effect of quality of education on improving entrepreneur intentions through risk taking is $41,2 \%$. This means that the parental role variable weakens the effect of the quality of education - entrepreneur intentions and risk taking - entrepreneur intentions.

Furthermore, based on the hypotheses testings, it can be concluded that: 1) the higher the risk taking, the higher entrepreneur intentions. 2) the higher the quality of education, the higher the entrepreneur intentions. 3) the higher the quality of education, the higher risk taking. 4) the parental role context has no effect on the correlation between quality of education and risk taking on entrepreneur intentions.

\section{REFERENCE}

Adamson, C. (2007). “Gendered anxieties: Islam, women's rights, and moral hierarchy in Java.” Anthropological Quarterly 80(1): 5-37.

Altinay, L., et al. (2012). "The influence of family tradition and psychological traits on entrepreneurial intention." International Journal of Hospitality Management 31(2): 489-499.

Azwar, S. (2005). "Signifikan atau sangat signifikan.” Buletin Psikologi UGM 13(1): 38-44.

Boukamcha, F. (2015). "Impact of training on entrepreneurial intention: an interactive cognitive perspective.” European Business Review 27(6): 593-616.

Chidiebere, O.-N., et al. (2014). "Youth Unemployment and Entrepreneurship Development: Challenges And Prospects In Nigeria." Kuwait Chapter of the Arabian Journal of Business and Management Review 4(4): 20.

Chlosta, S., et al. (2012). "Parental role models and the decision to become self-employed: The moderating effect of personality." Small Business Economics 38(1): 121-138.

Dalborg, C., et al. (2015). "Risk perception matters: why women's passion may not lead to a business start-up.” International Journal of Gender and Entrepreneurship 7(1): 87-104.

Ejdys, J. (2016). "Entrepreneurial Orientation vs. Innovativeness of Small and Medium Size Enterprises." Journal of Engineering, Project, and Production Management 6(1): 13

Gulo, W. (2002). Metodologi penelitian, Grasindo. 
Harry Matlay, P., et al. (2015). "Determinants of entrepreneurial intentions: Technical-vocational education and training students in Ethiopia." Education+ Training 57(8/9): 891-907.

Hassi, A. and G. Storti (2014). "Are Moroccan job seekers different than job creators? An exploratory study of differences in entrepreneurs and non-entrepreneurs.” World Journal of Entrepreneurship, Management and Sustainable Development 10(3): 198-208.

Ivanova Yordanova, D. and M. Ivanova Alexandrova-Boshnakova (2011). "Gender effects on risk-taking of entrepreneurs: evidence from Bulgaria." International Journal of Entrepreneurial Behavior \& Research 17(3): 272-295.

Kozubíková, L., et al. (2016). "The Role of Entrepreneur's Gender, Age and Firm's Age in Autonomy. the Case Study from the Czech Republic.” Economics \& Sociology 9(2): 168.

Malik, M. L. (2010). "Etos kerja pasar dan masjid."

Mardanshahi, M. M. (2015). "The role of life skills training on happiness and entrepreneurship characteristics of incoming students in Sari Agricultural Sciences and Natural Resources University students.” International Journal of Agriculture and Crop Sciences 8(3): 406.

Mitka, I. G. (2017). "Bricolage concept in risk culture assessment." European Journal of Sustainable Development 6(1): 335-343.

Moi, T., et al. (2011). "Young adult responses to entrepreneurial intent." Researchers World 2(3): 37.

Nafukho, F., et al. (2010). "Towards a search for the meaning of entrepreneurship." Journal of European industrial training 34(2): 110-127.

Nafukho, F. and S. P. Nkirina (2010). "The challenges of integrating entrepreneurship education in the vocational training system: An insight from Tanzania's Vocational Education Training Authority.” Journal of European Industrial Training 34(2): 153-166.

Popescu, C. C., et al. (2016). "An Analysis of the Determinants of Entrepreneurial Intentions among Students: A Romanian Case Study.” Sustainability 8(8): 771.

Ohiwerei, F. O. and B. O. Nwosu (2013). "The Role of Vocational and Technical Education in Nigeria Economic Development.” Educational Research Quarterly 36(3): 47.

Olanipekun, W. D., et al. (2015). "ENTREPRENEURIAL AND VOCATIONAL EDUCATION REVOLUTION: A CATALYST FOR SUSTAINABLE DEVELOPMENT.” Kuwait Chapter of the Arabian Journal of Business and Management Review 4(12): 32.

Sánchez Cañizares, S. M. and F. J. Fuentes García (2010). “Gender differences in entrepreneurial attitudes.” Equality, diversity and inclusion: an international journal 29(8): 766-786.

Smith, R. (2014). "Authoring second-generation entrepreneur and family business stories." Journal of Family Business Management 4(2): 149-170.

Subroto, W. T. (2013). "Entrepreneurship Development Course to Foster Character Merchandise in Support Economic Growth.” Asian Economic and Financial Review 3(6): 762. 